\title{
Brief report House mice with metacentric chromosomes in the Middle East
}

ÍSLAM GÜNDÜZ ${ }^{1}$, COŞKUN TEZ ${ }^{2}$ and JEREMY B. SEARLE ${ }^{3}$

${ }^{1}$ Department of Biology, Faculty of Arts and Sciences, University of Ballkesir, Ballkesir, Turkey

${ }^{2}$ Department of Biology, Faculty of Arts and Sciences, University of Erciyes, Kayseri, Turkey

${ }^{3}$ Department of Biology, University of York, PO Box 373, York YO10 5YW, UK

Correspondence: JB. Searle: Department of Biology, University of York, PO Box 373, York YO10 5YW, U.K. Tel: 4401904 432947; Fax: 4401904 432860; E-mail: jbs3@york.ac.uk

(Received September 29, 2000. Accepted October 30, 2000)

The western house mouse (Mus musculus domesticus) is standardly characterised by a karyotype of 40 acrocentric chromosomes. However, within the West European and North African parts of its range there are numerous local races defined by reduced chromosome numbers and metacentric chromosomes (review: NACHMAN and SEARLE 1995). The presence of metacentric chromosomes reflects the fusion of pairs of acrocentric chromosomes at their centromeres (Robertsonian fusions), any metacentrics so formed may evolve into other metacentrics by whole-arm reciprocal translocations (WARTs: HAUFFE and PIÁleK 1997). Races with metacentrics may be characterised by a diploid number as low as 22 chromosomes (CAPANNA et al. 1976).

Races with metacentrics either occur as singletons in geographical isolation or as clusters of related races with similar karyotypes in close geographic proximity (e.g., those in the Central Alps: GropP et al. 1982; PIÁleK et al. 2001). There has been a debate as to whether such isolated races/racial clusters are themselves related to each other or whether each focus of metacentric races arises independently. The sharing of particular chromosomes between such foci has been cited as evidence of their common origin (e.g., TICHY and VUCAK 1987), but this could be explained by convergent evolution. Molecular data have generally favoured an independent origin of each isolated race/racial cluster (BRITTON-DAVIDIAN et al. 1989; NACHMAN et al. 1994), although a recent microsatellite analysis has suggested that the isolated racial clusters in Central Italy and the Central Alps may have a common origin (RIGINOS and NACHMAN 1999).

The western house mouse is thought to have originated in the Middle East and spread into West Europe and North Africa within the last 10000 years as passive passengers of human migrations into those areas (BRITTON-DAVIDIAN et al. 1989; AufFray et al. 1990). Until the present report no mice with metacentric chromosomes had been described from the Middle East (GÜNDÜZ et al. 2000). This suggested that all metacentric chromosomes in the house mouse evolved recently (i.e., since the spread of the subspecies out of the Middle East) implying a high incidence of Robertsonian fusions and WARTs to explain the 100 or so different metacentrics found in West Europe and North Africa.

During a survey of mice in the Middle East we discovered one population with individuals that had metacentric chromosomes. The mice concerned were caught in a farm grain store at Denizli, Turkey $\left(37^{\circ}\right.$ $47^{\prime} \mathrm{N}, 28^{\circ} 59^{\prime}$ E) and had long tails and mitochondrial (mt) DNA sequences characteristic of Mus musculus domesticus. One individual had 38 chromosomes and was heterozygous for metacentrics 1.4 and 5.16 (where x.y refers to a metacentric formed from acrocentrics $x$ and y) (Fig. 1). The second individual examined from the same population had 38 chromosomes and was homozygous for metacentric 1.4. On the basis of the large size of one copy of chromosome 1 in this second individual, it carried a homogeneously staining region (HSR), as described elsewhere in Mus musculus (TraUT et al. 1984; AGULNIK et al. 1993). C-banding studies on mice from the population are needed to confirm this chromosome 1 polymorphism. Apart from the two mice that were used for G-banding studies, no other individuals were karyotyped within $192 \mathrm{~km}$ of the farm sampled, although further studies are planned.

This first case of metacentrics from the region of origin of the western house mouse is of significance because it implies that metacentrics could have spread with mice during the colonisation of West Europe and North Africa and that not all metacentrics in those areas need to have arisen in situ. The predominant $\mathrm{mt}$ DNA clade associated with Mus musculus domesticus from Turkey is also found in Greece, Spain, Portugal and Switzerland (GüNDÜZ et al. 2000), which could indicate spread of mice from 


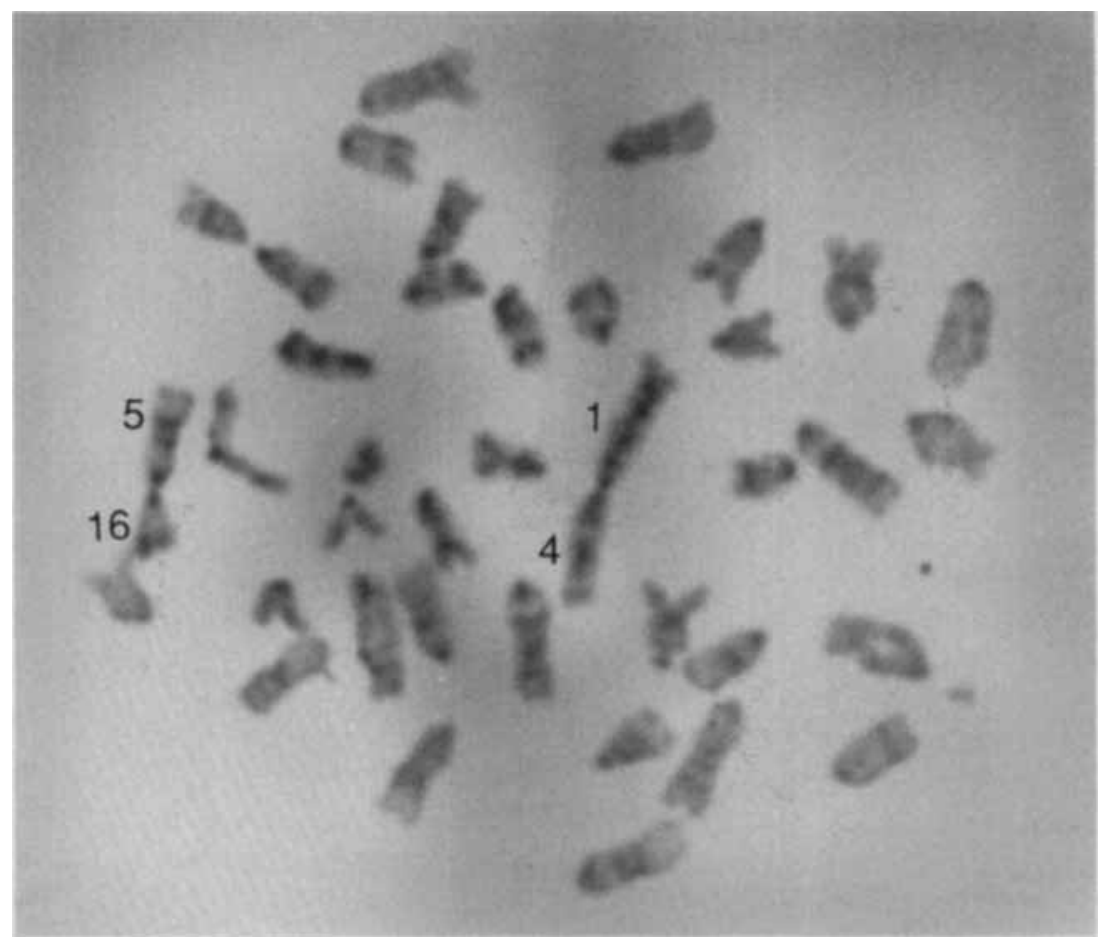

Fig. 1. G-banded mitotic metaphase spread of a 38-chromosome male mouse from Turkey carrying the metacentrics 1.4 and 5.16.

Turkey to those parts of Europe. The particular metacentrics that were found in Turkey have not been described elsewhere, but it would be of interest to conduct a microsatellite study analogous to that of RIGINOS and NACHMAN (1999) to establish whether the Turkish metacentrics are related to others by WARTs, especially those found in Greece, Spain and Switzerland.

Further studies of chromosome variation in Turkey and elsewhere in the Middle East would be desirable to determine the extent to which metacentric chromosomes are found in this region to help decide whether the phenomenal chromosomal variation in West Europe and North Africa has Middle Eastern roots.

\section{ACKNOWLEDGEMENTS}

We thank Drs H. Kefelioğlu (Ondokuz Mayis University, Turkey) and M. Korkmaz (Balıkesir University, Turkey) for laboratory facilities. We are grateful to the Department of Biology, University of York who provided financial support to İG.

\section{REFERENCES}

Agulnik S, Adolph S, Winking $\mathrm{H}$ and Traut W, (1993). Zoogeography of the chromosome $1 \mathrm{HSR}$ in natural populations of the house mouse (Mus musculus). Hereditas 119: 39-46.
Auffray J-C, Vanlerberghe $\mathrm{F}$ and Britton-Davidian J, (1990). The house mouse progression in Eurasia: a palaeontological and archaeozoological approach. Biol. J. Linn. Soc. 41: 13-25.

Britton-Davidian J, Nadeau JH, Croset $\mathrm{H}$ and Thaler L, (1989). Genic differentiation and origin of Robertsonian populations of the house mouse (Mus musculus domesticus Rutty). Genet. Res. 53: $29-44$.

Capanna E, Gropp A, Winking H, Noack $\mathrm{G}$ and Civitelli M-V, (1976) Robertsonian metacentrics in the mouse. Chromosoma 58: 341-353.

Hauffe HC and Piálek J, (1997). Evolution of the chromosomal races of Mus musculus domesticus in the Rhaetian Alps: the roles of whole-arm reciprocal translocation and zonal raciation. Biol. J. Linn. Soc. 62: 255-278.

Gropp A, Winking H, Redi C, Capanna E, Britton-Davidian J and Noack G, (1982). Robertsonian karyotype variation in wild house mice from Rhaeto-Lombardia. Cytogenet. Cell Genet. 34: 67-77.

Gündüz İ, Tez C, Malikov V, Vaziri A, Polyakov AV and Searle JB, (2000). Mitochondrial DNA and chromosomal studies of wild mice (Mus) from Turkey and Iran. Heredity 84: 458-467.

Nachman MW, Boyer SN, Searle JB and Aquadro CF, (1994). Mitochondrial DNA variation and the evolution of Robertsonian chromosomal races of house mice, Mus domesticus. Genetics 136: 1105-1120.

Nachman MW and Searle JB, (1995). Why is the house mouse karyotype so variable? Trends Ecol. Evol. 10: 397-402. 
Piálek J, Hauffe HC, Rodríguez-Clark KM and Searle JB, (2001). Raciation and speciation in house mice from the Alps: the role of chromosomes. Mol. Ecol. (in press).

Riginos C and Nachman MW, (1999). The origin of a Robertsonian chromosomal translocation in house mice inferred from linked microsatellite markers. Mol. Biol. Evol. 16: 1763-1773.
Tichy H and Vucak I, (1987). Chromosomal polymorphism in the house mouse (Mus domesticus) of Greece and Yugoslavia. Chromosoma 95: 31-36.

Traut W, Winking $\mathrm{H}$ and Adolph S, (1984). An extra segment in chromosome 1 of wild Mus musculus: a $\mathrm{C}$-band positive homogeneously staining region. Cytogenet. Cell Genet. 38: 290-297. 